\title{
ESTIMATE OF THE PREVALENCE OF TRANSMITTED DRUG RESISTANCE (TDR) AND ACQUIRED DRUG RESISTANCE (ADR) IN A HIV RESISTANCE STUDY OF THE GERMAN CLINSURV-HIV COHORT
}

\author{
doi:10.1136/sextrans-2013-051184.0193
}

'B Bartmeyer, 'D Schmidt, ' $\mathrm{C}$ Kollan, ${ }^{2} \mathrm{G}$ Fätkenheuer, ${ }^{3} \mathrm{H}$ Stellbrink, ${ }^{4} \mathrm{~J}$ Bogner, ${ }^{5} \mathrm{~B} O$ Jensen, ${ }^{6} \mathrm{M}$ Stoll, ${ }^{1} \mathrm{C}$ Kücherer, ${ }^{1} 0$ Hamouda. ${ }^{1}$ Robert Koch Institute, Berlin, Germany; ${ }^{2}$ Clinic for Internal Medicine, University of Cologne, Germany; ${ }^{3} \mathrm{CH}$ Study Centre Hamburg, Hamburg, Germany; ${ }^{4}$ Dept. of Infectious Diseases, Medical Clinic, Ludwig Maximilians University Munich, Germany; ${ }^{5}$ Clinic of Gastroenterology and Hepatology, Heinrich Heine University Düsseldorf, Germany; ${ }^{6}$ Clinic for Immunology and Rheumatology, Medical University Hanover, Germany

Aim To estimate the prevalence of HIV-TDR and ADR in one resistance study of the German ClinSurv-HIV cohort.

Method The ClinSurv study is a national open multi-centre long term observational cohort with 15 participating clinical centres ( $n=16,750$ patients; 31.12 .2011 ). In a resistance study all ClinSurv patients in five centres were identified. Sequences were processed through the Stanford University Genotypic Resistance Interpretation

Algorithm (www. hivdb.stanford.edu; HIVdb version 6.1.1F; 2012 webService version beta-1.0.1) to identify mutations and to determine drug susceptibility. Sequences were analysed by using different lists of mutations (Bennett D. 2009; Johnson V. 2011). Trends in the prevalence of drug resistance mutations were calculated by logistic regression.

Results A total of 9,528 patients from five study centres were included into analysis. 4,989 viral sequences were collected from $34 \%(3,267 / 9,528)$ of these patients. $47 \%(2,365 / 4,989)$ of sequences were produced from patients being treatment naïve and $50 \%$ $(2,495 / 4,989)$ from patients under treatment. TDR was identified in $10 \%(203 / 1,950)$ of viral strains. The prevalence of TDR over time was stable at $10.4 \%$ (95\% CI 9.1-11.8; OR: 0.98; 95\% CI 0.92-1.04; $\left.\mathrm{p}_{\text {for trend }}=0.6 ; 2001-2011\right)$. NRTI-resistance was determined in $7 \%$ (128/1,950), followed by 3\% NNRTI- and PI-resistance, respectively (NNRTI: 61/1,950; PI: 56/1,950). Prevalence of ADR in treated patients was high ( $61 \% ; 1,500 / 2,453$ of sequences) but declined significantly over time (OR: $0.8 ; 95 \%$ CI $0.77-0.83$; $\mathrm{p}_{\text {for trend }}<0.001$; 2001-2011). Within drug classes NNRTI-resistance was predominant $(56 \%$; 834/1503), followed by NRTI-resistance in $52 \%$ $(1,139 / 2,194)$ of sequences of patients with $\mathrm{ADR}$ exposed to these drug classes. PI-resistance was identified in 30\% (543/1778). Integrase-resistance was determined in $8 \%(13 / 161)$ of integrasesequences.

Discussion Prevalence of TDR is highly stable in this unselected study population, whereas $\mathrm{ADR}$ declined significantly over the time, indicating that this decline was presumably influenced by ART related effects, broader resistance testing and resistance test guided therapy. 


\section{STl 019.3 Estimate of the Prevalence of Transmitted Drug Resistance (TDR) and Acquired Drug Resistance (ADR) in a HIV Resistance Study of the German ClinSurv-HIV Cohort}

B Bartmeyer, D Schmidt, C Kollan, G Fätkenheuer, H Stellbrink, J

Bogner, B O Jensen, M Stoll, C Kücherer and O Hamouda

Sex Transm Infect 2013 89: A63

doi: 10.1136/sextrans-2013-051184.0193

Updated information and services can be found at:

http://sti.bmj.com/content/89/Suppl_1/A63.2

These include:

Email alerting service

Receive free email alerts when new articles cite this article. Sign up in the box at the top right corner of the online article.

Topic

Articles on similar topics can be found in the following collections

Collections

Drugs: infectious diseases (3182)

HIV / AIDS (2514)

HIV infections (2514)

HIV/AIDS (2514)

\section{Notes}

To request permissions go to:

http://group.bmj.com/group/rights-licensing/permissions

To order reprints go to:

http://journals.bmj.com/cgi/reprintform

To subscribe to BMJ go to:

http://group.bmj.com/subscribe/ 